\title{
MEASURING AND ANALYSIS OF COMPETITION INTENSITY IN THE SUGAR MARKET IN SERBIA
}

\author{
Bojan Krstić1, Vladimir Radivojevic ${ }^{2}$, Tanja Stanišić ${ }^{3}$
}

\begin{abstract}
Summary
Competition intensity is an important factor of social welfare in all market economies. The purpose of this paper is to establish a methodological framework for measuring and analyzing competition intensity in the sugar market in Serbia. There are several indicators of competition intensity that are used in market analysis. Results obtained by these indicators provide a good basis for objective, unbiased, and to some extent standardized reasoning and identification of anti-competitive behavior. The study is made by using descriptive statistics, comparative and correlation analysis. The results of the measurement of competition intensity in the sugar market in Serbia show significant problems in the process of establishing an efficient market economy in the Republic of Serbia. The paper is useful to the competition authority, providing significant findings of competitive conditions in the sugar market in Serbia, but also to the researchers in the field of market analysis, by providing them with an applicable methodological framework for measuring and analyzing competition intensity in the markets of other products in complex process industries.
\end{abstract}

Key words: competition, market concentration, market power, sugar market, Serbia

JEL: L11, L66, Q11

\section{Introduction}

There is generally accepted and deeply rooted belief in economic theory that intensifying competition increases efficiency of economy and social welfare. Efficiency is the goal, and the competition is a process that leads to achieving this goal, it became almost final conclusion on the matter. Under the influence of economic theory and practice, through the formulation

1 Bojan Krstić Ph.D., Associate Professor, University of Niš, Faculty of Economics, Trg Kralja Aleksandra Ujedinitelja no. 11, 18000 Niš, Serbia, Phone: +381 18528 685, E-mail: bojan.krstic@eknfak.ni.ac.rs

2 Vladimir Radivojević, Ph.D., Head of Financial Services, Ministry of Defense of the Republic of Serbia, Serbian Armed Forces, Čegarska street, 18000 Niš, Serbia, Phone: +381 18456 1926, E-mail: vladimir.radivojevic@ymail.com

3 Tanja Stanišić, Ph.D., Assistant Professor, University of Kragujevac, Faculty of Hotel Management and Tourism in Vrnjačka Banja, Vojvođanska street, 36210 Vrnjačka Banja, Serbia, Phone: +381 6449415 42, E-mail: tanja.stanisic@kg.ac.rs

EP 2016 (63) 2 (389-406) 
and implementation of economic and legal solutions for intervention in the market, almost all governments tend to intensify competition, restrict or prohibit the abuse of a dominant position in the market and any other behavior that distorts competition.

The goal of the governments is to maintain or create a competitive market that will encourage effective competition of economic entities. Intensive competition creates competitive pressure, i.e. the pressure that one market participant feels from all others. Each firm in a competitive environment tends to produce what consumers want, to reduce production costs and improve quality of their products and services, i.e. to be more efficient and effective than its competitors. Such behavior of market participants is the main stimulus of economic growth and a prerequisite for social welfare increase. Therefore, competition is seen as a desirable state of each market economy, and its intensity as a dynamic category which is reflected in the free entry into the market, the character of the price and the number of buyers and sellers.

The biggest problems for the establishing of competition is reflected in the identification of market structure and behavior that lead to restriction of competition. Due to the complexity, and in some cases even contradictions, the process of establishing of the competition is accompanied by many subjective and arbitrary assessments in different segments of the market analysis. Consequently, the existence of appropriate econometric apparatus for quantifying competition intensity between enterprises is an important prerequisite for the efficient implementation of competition policy which corresponds to the actual situation in the market.

The aim of this research is to provide an adequate methodological framework that can be applied in measuring and analyzing competition intensity in the sugar market in Serbia. The paper is structured in two segments: theoretical and empirical. Indicators of market concentration are shortly presented in theoretical background. Their practical application is made into the sugar market in Serbia, along with a set of other indicators of competition intensity in the empirical segment of the study. The research findings suggest recommendations to Serbian competition policy makers and represent a good basis for market analysis of other food products in complex process industries such as oil, milk, etc.

\section{Theoretical background - indicators of market concentration}

The importance of market concentration in the analysis of market performance has its foundation in structure-conduct-performance (SCP) paradigm. According to this paradigm, which source can be found in the theory of the Harvard economist Edward Mason in the 1930s, market structure determines market conduct and market conduct determines market performance (Lee, 2007). Although this paradigm has been sharply criticized in the past, indicators of market concentration are used to represent some performance of the market even today. Market structure cannot be the only indicator of market performance, but it certainly should be the first step in market analysis.

The importance of concentration indicators stems from their ability to demonstrate structural characteristics of the observed market (Bikker, Haaf, 2002). In early economic theory, it was developed set of concentration indicators that were immediately encountered wide 
application in empirical research (Marfels, 1971). Also, most contemporary textbooks of industrial economics provide a broad theoretical overview of the concentration indicators and methods of their calculation, including numerous illustrations of different market share distributions between firms (Ferguson, Ferguson, 1994; Lipczynski, Wilson, Goddard, 2009).

All indicators of market concentration could be classified as discrete (partial) and cumulative (aggregate). Discrete indicators observe only certain large companies, while cumulative indicators take into account all companies in the relevant market (Bikker et al., 2002; Stojanović, Radivojević, 2010). For the purposes of this paper, the following indicators from both categories were applied in the empirical research: the n-firm concentration ratio, the Herfindahl-Hirschman index, the Entropy index, the Relative entropy index, the Hall-Tideman index, the Rosenbluth index, the Hannah-Kay index, the Comprehensive concentration index, the Gini coefficient and the Lorenz curve.

Discrete indicators of market concentration, such as the n-firm concentration ratio, due to its properties (refer only to certain companies) has limited practical use. Furthermore, the Gini coefficient and the Lorenz curve measure the equality in the total market share distribution. This means that in a duopoly with 50\% market share of each participant, these indicators show the ideal market structure, whereby it neglects the extremely high concentration. These are the reasons why above indicators some authors call "unreliable" indicators of the market structure (Pisanie, 2013).

One of the most accurate and consequently the most commonly used indicator of market concentration is the Herfindahl-Hirschman index, which is defined as the sum of the squares of the market share of all firms in the relevant market (Davis, Garcés, 2010). This indicator has at least two advantages over the previously described discrete indices. First, it belongs to a group of cumulative indicators, and therefore provides more reliable result than discrete indicators. Second, due to the procedure of squaring market shares, firms with larger market share have special importance (higher weight).

The fact that the application of the Herfindahl-Hirschman index (HHI) in the market analysis is incorporated into the legal framework of the developed antitrust systems provides its superiority over other indicators. In the long-standing practice of controlling horizontal mergers between companies in the European Union (EU) and United States of America (USA) it was established market classification based on the value of HHI (European Commission, 2004; U.S. Department of Justice, Federal Trade Commission 2010). According to these classifications, there are three market categories:

1. Unconcentrated (EU: HHI below 0.10; USA: HHI below 0.15);

2. Moderately concentrated (EU: HHI between 0.10 and 0.20 ; USA: HHI between 0.15 and 0.25);

3. Highly concentrated (EU: HHI above 0.20; USA: HHI above 0.25).

Although Serbia has recently adopted a European system of market classification in merger control (Vlada Republike Srbije, 2016), both systems of classification EU and USA will be used to determine the category of sugar market in Serbia.

EP 2016 (63) 2 (389-406) 


\section{Research methodology and hypothesis}

The subject of this research is the use of indicators of competition intensity in order to evaluate competitive conditions in the sugar market in Serbia. The purpose of this paper is to establish a methodological framework for measuring and analyzing competition intensity in the sugar market in Serbia. In accordance with the purpose of research, the authors tested the following hypotheses:

H1: Sugar market in Serbia is characterized by a high degree of concentration with a dominant participant.

H2: Merger between two sugar producers leads to the formation of a duopoly with great market share of dominant participant.

H3: Sugar producers have significant market power in the primary agricultural market and final sugar market.

Information basis of this research consists of the official publications of the following authorities in Serbia: Ministry of Agriculture and Environmental Protection; Ministry of Trade, Tourism and Telecommunications; Statistical Office; Business Registers Agency; and Commission for the Protection of Competition.

The following research methods are used in the paper: descriptive statistics, comparative and correlation analysis. Comparative analysis is used to present relative position of each sugar producer in the market and to compare the degree of sugar market concentration mutually (in five-year period and a hypothetical situation) and with the thresholds set by developed antitrust systems in EU and USA. Correlation analysis is used to examine the interdependence between price aggregates in the sugar market.

\section{Research results and discussion}

Sugar is a strategically important food product and important raw material in almost all branches of the food industry. Therefore, sugar has a great impact on the standard of living of the population and on total costs of production in other branches of the food industry. Its participation in the average consumer basket for three-member's household is 3.5 kilograms per month, while average annual sugar consumption per capita is about 14 kilograms (Ministarstvo trgovine, turizma i telekomunikacija Republike Srbije, Potrošačka korpa).

The largest "consumer" of sugar is confectionery industry. There are more than 200 active confectionery companies in Serbia, and several of them are great exporters with strong market position in the CEFTA region (Lončar, Rajić, 2011). Consequently, the high price of sugar directly decreases the purchasing power of the population and increases production costs of other food products which are also part of the consumer basket, but also affects on the market position of domestic food producers in foreign markets.

Total sugar production in Serbia varies in the range from 404,000 to 591,000 tons in the period 2010-2015 (Ministarstvo poljoprivrede i zaštite životne sredine Republike Srbije, 2010-2015). Domestic consumption of sugar is at a constant level of about 250,000 tons per year: about 100,000 tons consumed in the human nutrition and about 150,000 tons used in 
further industrial processing. The remaining quantities are intended for export: 180,000 tons in EU countries in accordance with quota regime and the rest in CEFTA region countries. All these data indicate the importance of the sugar industry in economic development.

Due to absence of substitutes, sugar is a product with non-elastic demand and stable consumption. Because of customs and other barriers in Serbia, sugar import is negligibly low. In such circumstances, population and food industry are limited to consuming sugar from domestic producers. High import barriers and absence of substitutes provide the proper environment for abuse of market power by domestic producers. Therefore, an important task of competition authorities is to provide a stable supply of population and industry with sugar at competitive prices.

In the purpose of realizing the research goal and testing hypotheses, the empirical research of the sugar market in Serbia is structured in the following sections:

1. Market concentration of sugar market;

2. Market power of sugar producers.

\section{Market concentration of sugar market}

Sugar market in Serbia consists of six active sugar factories owned by the three large companies: Sunoko D.O.O., Hellenic Sugar Industry S.A. and Finanziaria Saccarifera ItaloIberica S.P.A. All sugar factories are located in Vojvodina: domestic company Sunoko has three active sugar factories in Vrbas, Pećinci and Kovačica; Greek company Hellenic Sugar has two factories in Crvenka and Žabalj; while factory in Senta is owned by Italian company Finanziaria S.I.I. Sugar market in Serbia has the character of the oligopoly market structure.

Measuring the concentration of sugar market is based on market share indicator. This indicator is calculated as the quotient of the revenue realized by the participant and total revenue of all participants in the relevant market (Krstić, Sekulić, 2013).

Sugar factories which are majority owned by a single company are regarded as related market participants (Table 1). Consequently, total annual revenue for forms of association represents the total annual revenue of associated participants.

Table 1. Total realized revenue (in thousands of RSD) and market share of sugar producers in Serbia; 2010-2014

\begin{tabular}{|c|l|r|r|r|r|}
\hline \multirow{2}{*}{ Year } & \multicolumn{1}{|c|}{ Indicator } & Sunoko D.O.O. & $\begin{array}{c}\text { Hellenic Sugar } \\
\text { Industry S.A. }\end{array}$ & $\begin{array}{c}\text { Finanziaria } \\
\text { S.I.I. }\end{array}$ & \multicolumn{1}{c|}{ Total } \\
\hline \multirow{2}{*}{2010} & Revenue & $17,465,564$ & $11,303,784$ & $6,196,027$ & $34,965,375$ \\
\cline { 2 - 6 } & Market share & 0.4995 & 0.3233 & 0.1772 & 1 \\
\hline \multirow{2}{*}{2011} & Revenue & $21,349,224$ & $11,963,688$ & $8,326,247$ & $41,639,159$ \\
\cline { 2 - 6 } & Market share & 0.5127 & 0.2873 & 0.2 & 1 \\
\hline \multirow{2}{*}{2012} & Revenue & $20,705,865$ & $10,449,428$ & $8,242,295$ & $39,397,588$ \\
\cline { 2 - 6 } & Market share & 0.5256 & 0.2652 & 0.2092 & 1 \\
\hline \multirow{2}{*}{2013} & Revenue & $23,252,853$ & $11,520,417$ & $8,652,616$ & $43,425,886$ \\
\cline { 2 - 6 } & Market share & 0.5355 & 0.2653 & 0.1993 & 1 \\
\hline
\end{tabular}




\begin{tabular}{|c|l|r|r|r|r|}
\hline Year & Indicator & Sunoko D.O.O. & $\begin{array}{c}\text { Hellenic Sugar } \\
\text { Industry S.A. }\end{array}$ & $\begin{array}{c}\text { Finanziaria } \\
\text { S.I.I. }\end{array}$ & \multicolumn{1}{c|}{ Total } \\
\hline \multirow{2}{*}{2014} & Revenue & $18,093,037$ & $11,134,645$ & $6,897,305$ & $36,124,987$ \\
\cline { 2 - 6 } & Market share & 0.5008 & 0.3082 & 0.1909 & 1 \\
\hline
\end{tabular}

Source: Agencija za privredne registre R. Srbije, 2010-2014

Sunoko has the largest market share in each of the observed years in the period 20102014, which is about half of the entire market (see Table1). Due to the fact that the market share indicator is not sufficient in the analysis of market concentration, the authors of this research use all indicators of competition intensity mentioned in theoretical background.

Analysis refers to the period 2010-2014 and the hypothetical market structure that would be formed after Sunoko/Hellenic Sugar merger. Commission for the Protection of Competition of the Republic of Serbia conditionally approved the merger between companies Sunoko and Hellenic Sugar on 13 February 2013 (Komisija za zaštitu konkurencije Republike Srbije, 2013). However, the merger, which is required by Sunoko, has not been implemented till today. Since there is a real possibility that this formally approved merger be implemented in practice, hypothetical market structure that would be formed after that merger is integral part of the analysis.

The values of concentration indicators of sugar market in Serbia in the period 2010-2014 are presented in Table 2 and Figure 1.

Table 2. The values of concentration indicators of the sugar market in Serbia; 20102014

\begin{tabular}{|l|c|c|c|c|c|c|}
\hline \multirow{2}{*}{ Concentration indicator } & \multirow{2}{*}{ Range } & \multicolumn{5}{|c|}{ Value } \\
\cline { 3 - 7 } & $\mathbf{2 0 1 0}$ & $\mathbf{2 0 1 1}$ & $\mathbf{2 0 1 2}$ & $\mathbf{2 0 1 3}$ & $\mathbf{2 0 1 4}$ \\
\hline $\begin{array}{l}\text { Concentration ratio of two } \\
\text { largest firms }\end{array}$ & $0<\mathrm{CR}_{\mathrm{n}} \leq 1$ & 0.82 & 0.80 & 0.79 & 0.80 & 0.81 \\
\hline $\begin{array}{l}\text { Herfindahl-Hirschman } \\
\text { index }\end{array}$ & $\frac{1}{n} \leq \mathrm{HHI} \leq 1$ & 0.39 & 0.39 & 0.39 & 0.40 & 0.38 \\
\hline Entropy index & $0 \leq \mathrm{EI} \leq \log \mathrm{n}$ & 1.02 & 1.02 & 1.02 & 1.01 & 1.03 \\
\hline Relative entropy index & $0 \leq \mathrm{REI} \leq 1$ & 0.93 & 0.93 & 0.93 & 0.92 & 0.94 \\
\hline Hall-Tideman index & $0<\mathrm{HTI} \leq 1$ & 0.40 & 0.42 & 0.42 & 0.43 & 0.42 \\
\hline Rosenbluth index & $0<\mathrm{RI} \leq 1$ & 0.27 & 0.28 & 0.27 & 0.27 & 0.28 \\
\hline $\begin{array}{l}\text { Hannah-Kay index } \\
(\alpha=2,5)\end{array}$ & 1 & 0.25 & 0.25 & 0.25 & 0.24 & 0.25 \\
\hline $\begin{array}{l}\text { Comprehensive } \\
\text { concentration index }\end{array}$ & $0<\mathrm{CCI} \leq 1$ & 0.73 & 0.73 & 0.73 & 0.73 & 0.73 \\
\hline Gini coefficient & $0 \leq \mathrm{GC} \leq 1$ & 0.16 & 0.16 & 0.16 & 0.17 & 0.15 \\
\hline
\end{tabular}

Source: Author's calculation 
Figure 1. The Lorenz curve of the sugar market in Serbia; $2014^{4}$

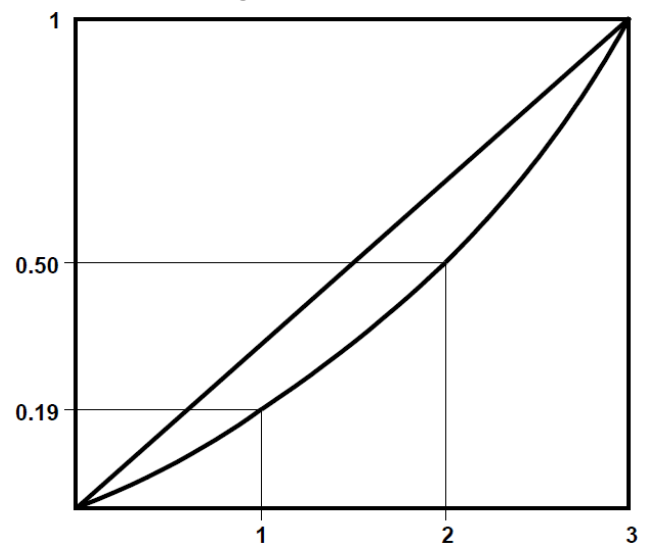

Source: Author's presentation

All results of market concentration for the period 2010-2014 substantiate the existence of a stable oligopolistic market structure in the sugar market in Serbia (see Table 2 and Figure 1). According to the previously mentioned thresholds set by the European Commission, which Serbia has adopted recently, but also to those prescribed by the United States Department of Justice and the Federal Trade Commission, that are shown in the theoretical background of this paper, the sugar market in Serbia is located in the zone of high concentration. It should be noted that the degree of concentration is significantly above the lower limit of the high concentration zone. Results obtained using the HHI clearly indicates this conclusion. This index shows that the level of sugar market concentration exceeds the lower limit of the high concentration zone by more than 0.18 index points according to the European classification system, i.e. 0.13 index points according to the American classification system.

Analysis of the results obtained by $n$-firm concentration ratio, Hall-Tideman index, Rosenbluth index, Hannah-Kay index and Comprehensive concentration index leads to almost the same conclusion as well as in the case of HHI (see Table 2 and Figure 1). However, due to the small number of participants in the relevant market, the results obtained by Entropy index, Relative entropy index, Gini coefficient and to some extent Lorenz curve should be accepted only in part.

It is especially important to note that the degree of (already) extremely high concentration will be significantly increased if the merger between first and second participant by market share (Sunoko/Hellenic Sugar) be conducted, i.e. if the hypothetical market structure be established. The values of concentration indicators of sugar market in Serbia in the hypothetical market structure are presented in Table 3 and Figure 2.

4 Due to approximately equal disperson of market shares between companies in the period 20102014, Lorenz curves for each year in this period are almost the same. Thus, Figure 1 presents graphical views of the Lorenz curve for 2014, as a represent year for period 2010-2014.

EP 2016 (63) 2 (389-406) 
Table 3. The values of concentration indicators of the sugar market in Serbia in the hypothetical market structure

\begin{tabular}{|l|c|}
\hline \multicolumn{1}{|c|}{ Concentration indicator } & $\begin{array}{c}\text { Value in the hypothetical market } \\
\text { structure }\end{array}$ \\
\hline Concentration ratio of two largest firms & 1 \\
\hline Herfindahl-Hirschman index & 0.69 \\
\hline Entropy index & 0.53 \\
\hline Relative entropy index & 0.48 \\
\hline Hall-Tideman index & 0.72 \\
\hline Rosenbluth index & 0.38 \\
\hline Hannah-Kay index $(\alpha=2,5)$ & 0.60 \\
\hline Comprehensive concentration index & 0.87 \\
\hline Gini coefficient & 0.21 \\
\hline $\begin{array}{l}{ }^{*} \text { It is assumed that all market participants keep } \\
\text { their market share from 2014 }\end{array}$ & \\
\hline
\end{tabular}

Source: Author's calculation

Figure 2. The Lorenz curve of the sugar market in Serbia in the hypothetical market structure

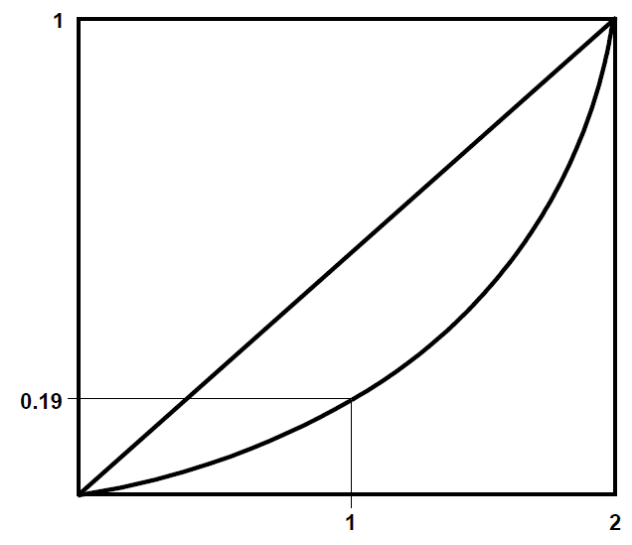

Source: Author's presentation

Differences between values of all indicators of market concentration in Table 2 and Table 3, but also the difference between Lorenz curves in Figure 1 and Figure 2 confirm a significant increase of market concentration in the case of the hypothetical market structure compared to the market concentration in the period 2010-2014.

Comparison of the HHI value in 2014 (Table 2) and in hypothetical market structure (Table 3) indicates an increase of 0.31 points. How much is it increasing actually and how attention is given to such mergers in developed antitrust systems, clearly indicates EU and USA antitrust practice. All horizontal mergers in the market that is classified in the high concentration zone, which lead to increase the value of HHI more than 0.01 points in the US, and 0.015 in the European and Serbian antitrust system, raises "great concern" to the regulators (European Commission, 2004; U.S. Department of Justice et al., 2010; Vlada Republike Srbije, 2016). 
The threshold of a great concern in the EU and Serbia is more than twenty times smaller, and in the USA more than thirty times smaller than the value change of HHI that will be reached after hypothetical merger between companies Sunoko and Hellenic Sugar.

Table 4 presents the results of descriptive statistics for values of concentration indicators of the sugar market in Serbia in the period 2010-2014.

Table 4. Results of descriptive statistics for values of concentration indicators of sugar market in Serbia; 2010-2014

\begin{tabular}{|l|c|c|c|c|c|c|}
\hline \multicolumn{1}{|c|}{$\begin{array}{c}\text { Concentration } \\
\text { indicator }\end{array}$} & $\mathbf{N}$ & Minimum & Maximum & Mean & $\begin{array}{c}\text { Standard } \\
\text { deviation }\end{array}$ & $\begin{array}{c}\text { Coefficient of } \\
\text { variation }\end{array}$ \\
\hline $\begin{array}{l}\text { Concentration ratio of } \\
\text { two largest firms }\end{array}$ & 5 & 0.79 & 0.82 & 0.8040 & 0.01140 & 0.014 \\
\hline $\begin{array}{l}\text { Herfindahl-Hirschman } \\
\text { index }\end{array}$ & 5 & 0.38 & 0.40 & 0.3900 & 0.00707 & 0.018 \\
\hline Entropy index & 5 & 1.01 & 1.03 & 1.0200 & 0.00707 & 0.007 \\
\hline Relative entropy index & 5 & 0.92 & 0.94 & 0.9300 & 0.00707 & 0.008 \\
\hline Hall-Tideman index & 5 & 0.40 & 0.43 & 0.4180 & 0.01095 & 0.026 \\
\hline Rosenbluth index & 5 & 0.27 & 0.28 & 0.2740 & 0.00548 & 0.020 \\
\hline Hannah-Kay index & 5 & 0.24 & 0.25 & 0.2480 & 0.00447 & 0.018 \\
\hline $\begin{array}{l}\text { Comprehensive } \\
\text { concentration index }\end{array}$ & 5 & 0.73 & 0.73 & 0.7300 & 0 & 0 \\
\hline Gini coefficient & 5 & 0.15 & 0.17 & 0.1600 & 0.00707 & 0.044 \\
\hline
\end{tabular}

Source: Author's calculation (SPSS 22)

Due to the fact that the values of all concentration indicators observed in Table 4 are close to the mean, the standard deviation for each concentration indicator is very low. Such value of standard deviation implies that there is very low variability and heterogeneity of values of concentration indicators. This is also confirmed by calculation of the coefficient of variation (see Table 4). The highest value of the coefficient of variation is recorded in the case of the Gini coefficient (0.044), and the lowest in the case of the Comprehensive concentration index, where variation is not observed. Results of descriptive statistics confirm that there was a stable oligopolistic market structure in the sugar market in Serbia in the period 2010-2014, with a minor change of values of concentration indicators.

\section{Market power of sugar producers}

It would be completely wrong only on the basis of high values of almost all concentration indicators conclude that prevention of sugar market concentration is socially desirable. Sugar production belongs to the group of process industries with the tendency of concentration in almost all EU countries. In such circumstances, concentration is often a necessary precondition for efficiency increase, modernization and competitiveness of domestic products. Therefore, if competition policy a priori prevents any change that leads to increase market concentration, it opens a space for wrong decisions.

The market structure is a useful first step in the analysis of competition, but it should not be 
the only. The behavior of market participants should be the focus of regulatory authorities. Therefore, the following analysis examines the behavior of sugar producers, especially in the area of impact on primary producers and final consumers.

Sugar industry represents a complex and mutually-conditioned system of food production, from agricultural raw materials (sugar beet) to final food products (sugar). In such industries it is very important to observe relationships and parity of prices by stages of reproduction, because it provides insight into the status of each sub-industrial sector, i.e. allows analysis of position and mutual dependence of each segment in the agricultural and food production.

Relations between the prices into different stages of reproduction are clear indications of the competition state within the entire production system. Parity exchange of products occurs in an ideal market structure of perfect competition. Unfortunately, such exchange is almost impossible in practice, so disparities are reality of economic relations between market participants. Nevertheless, large price deviation and instability between different stages of same industry indicate a lack of competition.

Comparative review of average annual purchase prices of sugar beet and average annual retail prices of sugar for the period from 2000/2001 to 2014/2015 is presented in Table 5. It should be noted that retail food prices (in this case: the prices of sugar) in the current year adapt to the purchase prices of primary agricultural products (in this case: the prices of sugar beet) from the previous year. It should also be noted that the retail price of sugar includes trading margin and value added tax.

Table 5. Comparative review of sugar beet purchase prices and sugar retail prices (chain indices); 2000/2001-2014/2015

\begin{tabular}{|c|c|c|c|c|c|}
\hline \multicolumn{2}{|c|}{ Purchase price of sugar beet } & \multicolumn{3}{c|}{ Retail price of sugar } \\
\hline Year & RSD/kg & Index & Year & RSD/kg & Index \\
\hline 2000 & 1.56 & 100 & 2001 & 40.15 & 100 \\
\hline 2001 & 1.79 & 115 & 2002 & 45.60 & 114 \\
\hline 2002 & 1.76 & 98 & 2003 & 41.36 & 91 \\
\hline 2003 & 1.75 & 99 & 2004 & 42.02 & 102 \\
\hline 2004 & 1.90 & 109 & 2005 & 51.87 & 123 \\
\hline 2005 & 2.07 & 109 & 2006 & 65.05 & 125 \\
\hline 2006 & 2.41 & 116 & 2007 & 64.40 & 99 \\
\hline 2007 & 2.42 & 100 & 2008 & 58.65 & 91 \\
\hline 2008 & 2.67 & 110 & 2009 & 61.40 & 105 \\
\hline 2009 & 2.61 & 98 & 2010 & 68.22 & 111 \\
\hline 2010 & 2.51 & 96 & 2011 & 106.28 & 156 \\
\hline 2011 & 3.87 & 154 & 2012 & 93.82 & 88 \\
\hline 2012 & 4.38 & 113 & 2013 & 89.64 & 96 \\
\hline 2013 & 4.45 & 102 & 2014 & 72.41 & 81 \\
\hline 2014 & 3.62 & 81 & 2015 & 68.42 & 95 \\
\hline
\end{tabular}

Source: Author's calculation based on data of Statistical Office of the Republic of Serbia, 20002014; Ministarstvo trgovine, turizma i telekomunikacija R. Srbije, 2010-2015; 
Comparison of the change in chain indices derived in Table 5 indicates the instability and the spread of parity range between the price of raw materials and price of the final product in the last fifteen years. It is particularly unusual that there is noticed an atypical and unexpected deviation of these reproductive-conditioned categories in certain years. The fact that these deviations have a cyclic character is especially unusual. It is evident in Figure 3.

Figure 3. The movement of chain indices presented in Table 5

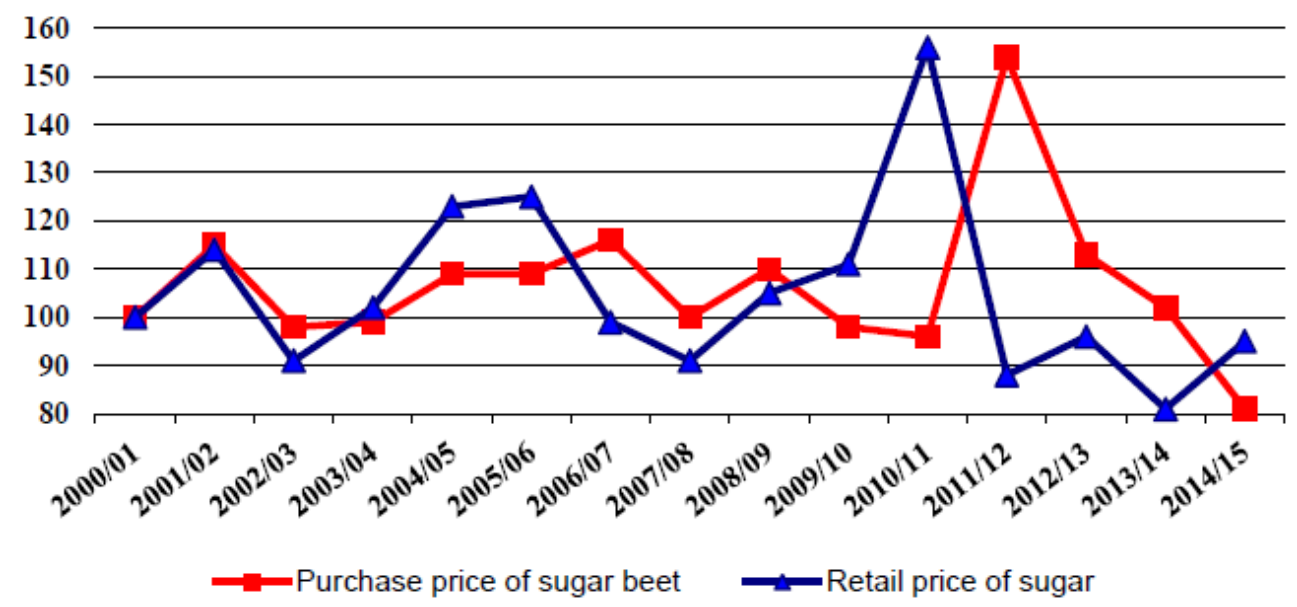

Source: Work of authors

During the period from 2000/01 to 2003/04 there is a fairly uniform ratio of the movement of sugar beet purchase prices and retail prices of the final product (see Figure 3 ), almost like in an ideal market structure of perfect competition. However, since $2004 / 05$ parity range grows and culminates in 2010/11 and 2011/12. It is particularly indicative that since 2004/05 there is a cyclical movement of parity ranges. In other words, there is a cyclic rotation of parity positions between primary producers and processors of sugar beets. This fact suggests the conclusion that sugar beet purchase price has influenced the formation of sugar retail price as much as sugar retail price has influenced the formation of sugar beet purchase price. Such unusual relationship is the most visible in the period from $2009 / 10$ to $2014 / 15$.

After reducing the price of sugar beet by $2 \%$ in 2009, there was an increase in the price of sugar by $11 \%$ in 2010 (see Table 5 and Figure 3). Sugar beet price continued to fall in 2010 , this time for $4 \%$, but the sugar price has increased in 2011 for the whole $56 \%$. The high price of sugar in 2011 enabled the processors to purchase sugar beet crop from the 2011 at a price $54 \%$ higher than the price in 2010 . The disparity is significantly reduced after that period, but far from being negligible. Finally, there is another rotation of parity positions between primary producers and processors of sugar beet in 2014/15.

Analysis of market power in the sugar industry using the vertical parity of prices indicates that the production and purchase prices of raw materials depend a lot on the price of the final product. This confirms that a key role in the formation of sugar beet 
purchase price have the processors (sugar producers), regardless of the movement of its production and the total quantity supplied. The potential for a casual increase of primary products purchase prices lies in the relatively high prices of the final products in which there is always space for relatively higher prices of raw materials. ${ }^{5}$ This can be clearly indicated in the analysis of parity of prices in which it will be taken into consideration technological coefficients of industrial processing. Table 6 shows parity of sugar beet purchase prices and sugar production prices in the period from 2000/2001 to $2014 / 2015$.

Table 6. Parity of sugar beet purchase prices and sugar production prices; 2000/20012014/2015

\begin{tabular}{|c|c|c|c|}
\hline Year & $\begin{array}{c}\text { Purchase price of } \\
\text { sugar beet (RSD/ } \\
\mathbf{k g} \text { ) }\end{array}$ & $\begin{array}{c}\text { Production price of } \\
\text { sugar (RSD/kg) }\end{array}$ & Parity of prices \\
\hline 1 & 2 & 3 & $3: 2$ \\
\hline $2000 / 2001$ & 1.56 & 28.10 & 18.01 \\
\hline $2001 / 2002$ & 1.79 & 31.92 & 17.82 \\
\hline $2002 / 2003$ & 1.76 & 28.95 & 16.45 \\
\hline $2003 / 2004$ & 1.75 & 29.41 & 16.81 \\
\hline $2004 / 2005$ & 1.90 & 36.25 & 19.08 \\
\hline $2005 / 2006$ & 2.07 & 45.54 & 22.00 \\
\hline $2006 / 2007$ & 2.41 & 45.08 & 18.71 \\
\hline $2007 / 2008$ & 2.42 & 41.06 & 16.97 \\
\hline $2008 / 2009$ & 2.67 & 42.98 & 18.30 \\
\hline $2009 / 2010$ & 2.61 & 47.75 & 29.64 \\
\hline $2010 / 2011$ & 2.51 & 74.40 & 16.97 \\
\hline $2011 / 2012$ & 3.87 & 65.67 & 14.33 \\
\hline $2012 / 2013$ & 4.38 & 62.75 & 11.39 \\
\hline $2013 / 2014$ & 4.45 & 50.69 & 13.23 \\
\hline $2014 / 2015$ & 3.62 & 47.90 & \\
\hline${ }^{*}$ The retail price of sugar decreased for $30 \%$ (trading margin and value added tax) \\
\hline
\end{tabular}

Source: Author's calculation based on data of Statistical Office of the Republic of Serbia, 20002014; Ministarstvo trgovine, turizma i telekomunikacija R. Srbije, 2010-2015

Technological coefficient of industrial processing of sugar beet in Serbian conditions orders that production of one kilogram of sugar requires about seven kilograms of sugar beet. ${ }^{6}$ Theoretically, the ideal price-parity exchange between primary producers and processors, i.e. exchange which allows processors to cover costs of purchase raw

5 Very similar research results on the relationship between primary producers and processors were obtained in the analysis of Serbian oil industry (Milanović, 2011). Also, the situation is similar in the milk and dairy products market (Stojanović, Radivojević, 2011).

6 The average digestion (quantity of sucrose) of processed sugar beet in Serbia in ranges between $13 \%$ and 16\% (Ministarstvo poljoprivrede i zaštite životne sredine Republike Srbije, 2010-2015). 
materials, can be presented as follows: sugar beet:sugar=1:7. Due to the fact that the industrial process, except costs of purchase raw materials, generates other costs, as well as the pursuit of making a profit, it is quite understandable that in practice this ratio will be higher, i.e. that the price of sugar must be above 7 . However, large deviation ratio can be an indicator of violation of the competitive conditions. Graphical presentation of the parity of prices is shown in Figure 4, whereby it is assumed that purchase price of sugar beet $=1$.

Figure 4. Parity of prices calculated in Table 6 (purchase price of sugar beet $=1$ )

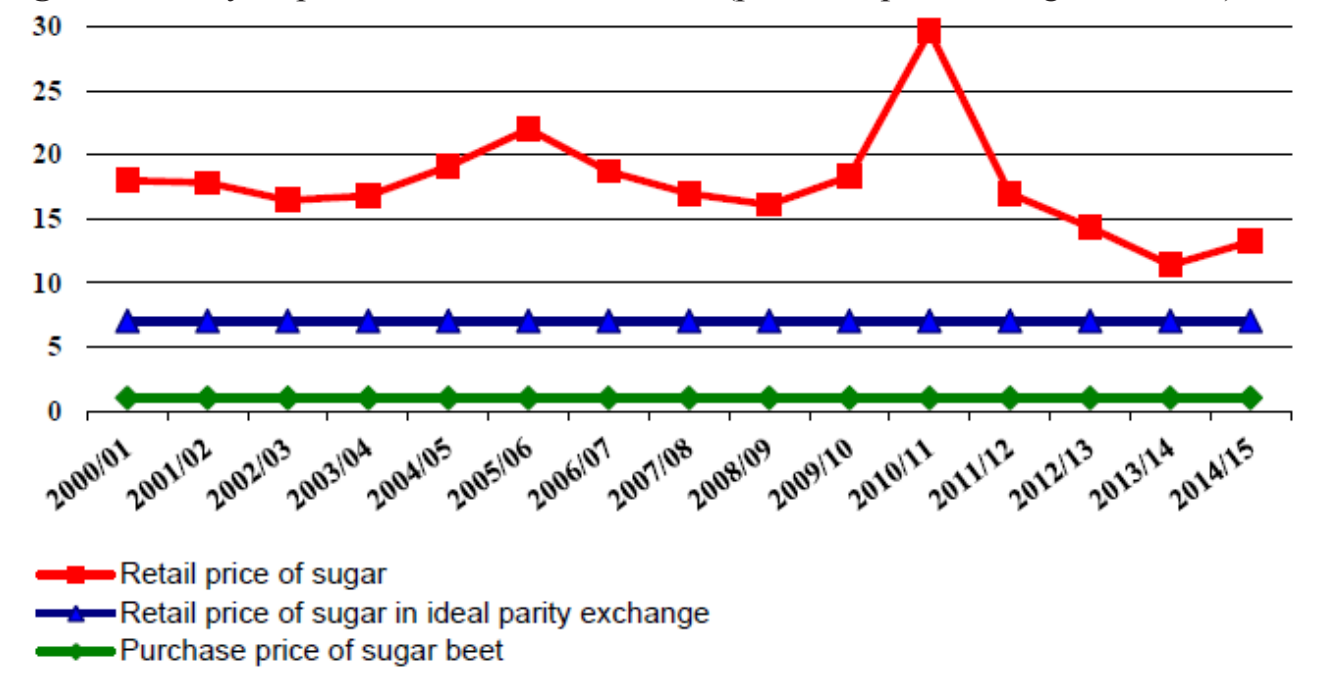

Source: Work of authors

During the observed period, the average price disparity is 17.72 (see Table 6). Nevertheless, it is a noticeable sharp expansion and the narrowing of parity ranges (see Figure 4). The parity in 2010/11 amounted its maximum to even 29.64, and already three years after that was reduced to 11.39. This leads to the conclusion that the price of raw materials did not significantly affect the price of the final products.

In order to examine the interdependence between sugar beet purchase prices and sugar retail prices, the method of Pearson's correlation analysis is applied (see Table 7).

Table 7. Pearson's correlation coefficient between sugar beet purchase prices and sugar retail prices, 2010-2014

\begin{tabular}{|l|l|l|}
\hline \multicolumn{2}{|c|}{ Sugar retail prices } \\
\hline Sugar beet purchase prices & Pearson's Correlation & $0.686(* *)$ \\
\hline & Sig. (2-tailed) & 0.005 \\
\hline & N & 15 \\
\hline$* *$ Correlation is significant at the 0.01 level (2-tailed) \\
\hline
\end{tabular}

Source: Author's calculation (SPSS 22) 
The determined value of the Pearson's correlation coefficient between sugar beet purchase prices and sugar retail prices of 0.686 indicates a moderate positive correlation. In this way, it can be concluded that the sugar beet purchase prices have moderate (but not significant) impact on sugar retail prices in the period 2010-2014.

All previous findings focus further analysis onto sugar producers and retail sugar prices. Figure 5 shows trends in the domestic retail price of sugar in the period from December 2010 to December 2015, with the intersection of four months.

Figure 5. Retail prices of sugar (RSD/kg) in Serbia; December 2010-December 2015

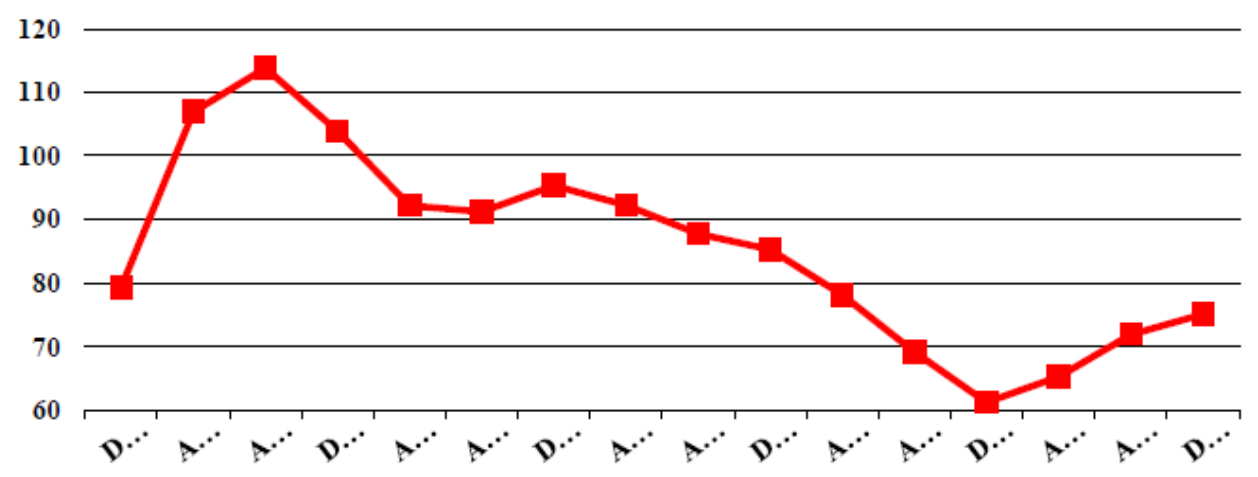

Source: Ministarstvo trgovine, turizma i telekomunikacija R. Srbije, 2010-2015

The average retail price in December 2010 was $79 \mathrm{din} / \mathrm{kg}$ (see Figure 5). After three months the price was increased to nearly $107 \mathrm{din} / \mathrm{kg}$ (an increase of almost 35\%). Next months the price continued to grow, and in August reached its maximum of $114 \mathrm{din} / \mathrm{kg}$, which is an increase of about $45 \%$ compared to the price in December 2010. The fact that the sugar price has not reflected the real production costs in this period was confirmed by a sudden decrease of price to $91 \mathrm{RSD} / \mathrm{kg}$ in April 2012. Practically, manufacturers have been forced to reduce the price more than $20 \mathrm{RSD} / \mathrm{kg}$ after intervention of the Directorate for Commodity Reserves, which sold 12,000 tons of sugar at the price of $95 \mathrm{RSD} / \mathrm{kg}$.

Price stability during 2012 and a part of 2013 was provided through state interventionism. After that there was a continuous reduction of sugar prices up to December 2014, when the price reaches its minimum of $61 \mathrm{RSD} / \mathrm{kg}$ (see Figure 5). Next year the price has risen to $75 \mathrm{RSD} / \mathrm{kg}$. This analysis enforces a question of what are the reasons that the price of sugar in one year (from December 2010 to December 2011), first rises sharply by as much as $45 \%$, and then rapidly declines of around $20 \%$ ? Also, what are the reasons that the price of sugar in December 2014 is almost halfway lower than the price from August 2011?

Due to the fact that this market is specific, because sugar is a homogeneous product with non-elastic demand and stable consumption without seasonal variations, the answer can only be found in the absence of competition. This assumption can be tested by analyzing the movement of domestic and export prices of sugar, because this way 
it can be compared the behavior of domestic producers in the domestic market, which is characterized by "lack of competition" with the behavior of domestic producers in foreign markets, mainly characterized by a high degree of competition.

Figure 6 shows trends in domestic and export prices of sugar from January 2011 to January 2012. This period was chosen because the previous analysis has shown that there were great changes during the year. The movement of price aggregates shows variations of parity relations between domestic and export prices of sugar.

Figure 6. Comparative review of sugar prices in domestic market and sugar export prices $(\mathrm{USD} / \mathrm{t})^{7}$

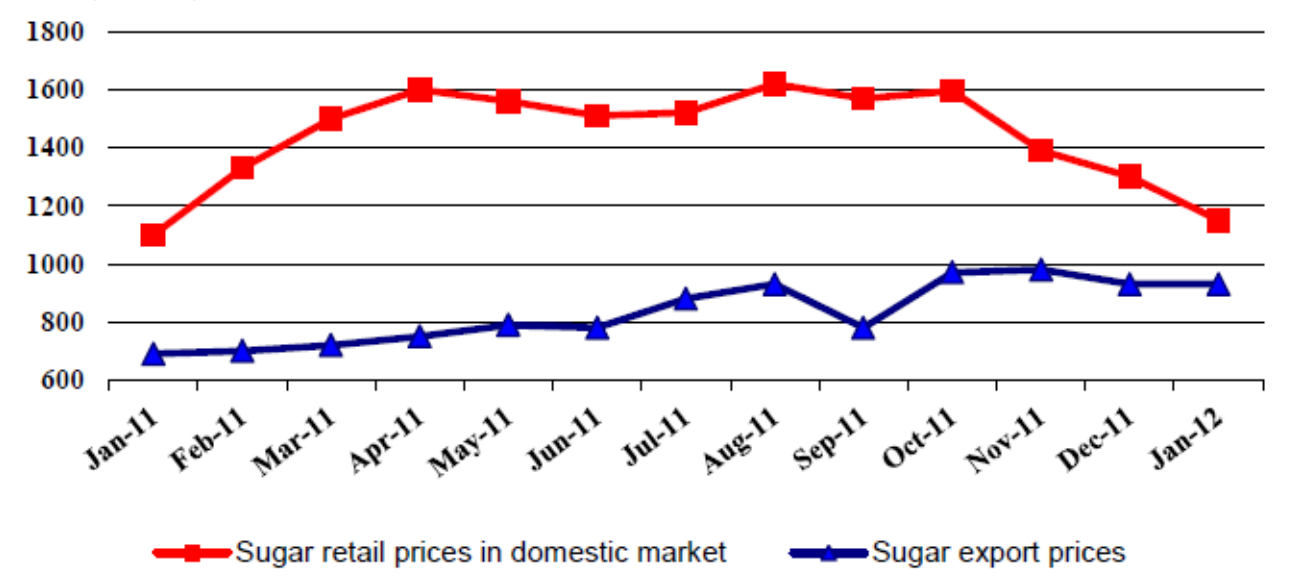

Source: Ministarstvo poljoprivrede i zaštite životne sredine R. Srbije, Izveštaj o šećeru, Februar 2012

The domestic prices of sugar were 57\% higher than export prices in January 2011. Due to the rapid growth of domestic prices in the next two months, the range of parity in April reached a record of even 120\%. Next nine months (from May 2011 to January 2012) parity range decreased from $120 \%$ to only $25 \%$. From Figure 6 it can be concluded that the sharp rise and then a sudden drop of domestic retail prices are not accompanied by any such changes of export prices. On the contrary, the analysis showed that sugar producers during the setting domestic and export prices do not have the same or even similar criteria.

\section{Conclusions}

The calculation of concentration indicators of the sugar market in Serbia showed a significant information capacity of the findings in terms of market structure characteristics. It is shown that these findings, together with results obtained by using the set of indicators for measuring market power provide clear insight into the

7 Export prices include the retail and wholesale prices, while domestic prices include only retail prices. However, it has no influence on the ratio of these two categories, i.e. these differences will not affect the validity of the analysis. The ratio of these prices in the competitive market must be constant or with small deviations.

EP 2016 (63) 2 (389-406) 
competitive conditions and allow identification of anti-competitive conduct.

It is important to note the fact that each of used indicators of competition intensity carries with itself certain limitations, so comprehensibility and the applicability of the results often depend on the analytical and subjective assessment of researchers. In other words, each market presents a "case for itself". Therefore, taking into account the specifics of the case and the analysis period is an important principle in choosing the most appropriate technique or set of techniques that will be used to measure competition intensity.

Empirical analysis conducted in the sugar market in Serbia suggests verification of all hypotheses. It is shown that the sugar market is characterized by an extremely high degree of concentration of supply, i.e. the existence of pure oligopoly with a dominant participant and two followers (confirmed H1). It was also pointed the existence of strong tendencies of further market concentration, which would lead to the formation of duopoly with $80 \%$ market share of the dominant participant (confirmed H2). Beside indicators of market concentration, the authors applied a range of additional indications and techniques in order to present a complete overview of the market, the dynamics of its structure and competition intensity. Their focus was onto the behavior of companies, i.e. onto the market power of the sugar producers. Consequently, particular attention was paid to analysis of product prices correlation between different stages of industrial production. All research findings indicate the existence of significant market power of sugar producers in the primary and final market. The main conclusion is that sugar producers have significant market share and market power in both markets in terms of impact onto the sugar beet prices, as well as onto the final product prices (confirmed H3).

Empirical research suggests complex problems facing Serbia in the competition policy area, where the sugar market has served only as a good example to research and demonstrate consequences of these problems. The conclusions of this study can contribute to better understanding of the application of quantitative methods in competitive conditions analysis, but also applied methodological framework can be used in market analysis of any other food product in process industries.

\section{References}

1. Agencija za privredne registre Republike Srbije(2010-2014): Godišnjifinansijski izveštaji privrednih društava. (Retrieved from http://pretraga2.apr.gov.rs/ObjedinjenePretrage/ Search/Search 2016 Feb 10).

2. Bikker, J., Haaf, K. (2002): Measures of competition and concentration in banking industry: A review of literature. Economic and Financial Modelling, Vol. 9, No. 2, pp. 53-98.

3. Davis, P., Garcés, E. (2010): Quantitative techniques for competition and antitrust analysis (ISBN: 978-0-691-14257-9). Princeton University Press, Princeton, New Jersey.

4. Ferguson, P.R., Ferguson, G.J. (1994): Industrial economics: Issues and perspectives (ISBN: 978-0-814-72625-9). Macmillan, London, United Kingdom. 
5. Komisija za zaštitu konkurencije Republike Srbije (2013): Rešenje broj 6/0-02-3/201315. (Retrieved from http:/www.kzk.gov.rs/kzk/wp-content/uploads/2013/02/MicrosoftWord-.pdf 2016 Jan 10).

6. Krstić, B., Sekulić, V. (2013): Upravljanje poslovnim performansama (ISBN: 978-866139-066-1). Ekonomski fakultet, Niš, Srbija.

7. Lee, C. (2007): SCP, NEIO and beyond. Working Paper, The International Centre for the Study of East Asian Development, No. 5, Kitakyushu, Japan.

8. Lipczyinski, J., Wilson, J., Goddard, J. (2009): Industrial organization: Competiton, strategy, policy (ISBN: 978-0-273-71038-7). Prentice Hall, Harlow, United Kingdom.

9. European Commission (2004): Guidelines on the assessment of horizontal mergers under the council regulation on the control of concentrations between undertakings. Official Journal of the European Union (C 31), pp. 5-18. (Retrieved from http://eur-lex.europa. eu/legal-content/EN/TXT/PDF/?uri=CELEX:52004XC0205(02)\&from=EN 2016 Jan 17).

10. Vlada Republike Srbije (2016): Uredba o sadržini i načinu podnošenja prijave koncentracije. Službeni glasnik Republike Srbije, Br. 5/2016. (Retrieved from http:// www.kzk.gov.rs/kzk/wp-content/uploads/2016/02/Uredba-o-sadr\%C5\%BEini-ina\%C4\%8Dinu-podno\%C5\%A1 enja-prijave-koncentracije-Sl.-gl.-RS-br.-5-2016.pdf 2016 Mar 17).

11. Lončar, D., Rajić, V. (2011): Analysis of competition and concentration in the confectionery products market in Serbia. Ekonomika preduzeća, Savez ekonomista Srbije, Vol. 58, No. 7-8, pp. 367-378, Beograd, Srbija.

12. Marfels, C. (1971): Absolute and relative measures of concentration reconsidered. Kyklos, Wiley-Blackwell, Vol. 24, No. 4, pp. 753-766, Hoboken, New Jersey.

13. Milanović, M. (2011): Ekonomske promene u reprodukcionoj vertikali industrije ulja u Srbiji - dugoročni trendovi. Industrija, Ekonomski institut, Vol. 39, No. 4, pp. 107-126, Beograd, Srbija.

14. Ministarstvo poljoprivrede i zaštite životne sredine Republike Srbije (2010-2015): Izveštaji o šéceru. (Retrieved from http://www.mpzzs.gov.rs/dokumenti/ 2016 Feb 29).

15. Ministarstvo trgovine, turizma i telekomunikacija Republike Srbije (2010-2015): Kupovna moć stanovništva: Potrošačka korpa. Mesečni izveštaji. (Retrieved from http:// mtt.gov.rs/informacije/potrosacka-korpa/2016 Feb 25).

16. Pisanie, J. (2013): Concentration measures as an element in testing the structure-conductperformance paradigm. ERSA Working Paper, National Treasury of South Africa, No. 345, South Africa.

17. Statistical Office of the Republic of Serbia (2000-2014): Monthly statistical bulletin. (Retrieved from http://webrzs.stat.gov.rs/WebSite/Public/PageView.aspx?pKey=140 2016 Feb 28).

18. Stojanović, B., Radivojević, V. (2010): Koncentracija ponude kao izraz nesavršenosti tržišta: Primer nespecijalizovane trgovine na malo na tržištu grada Niša. Ekonomika 
preduzeća, Savez ekonomista Srbije, Vol. 58, No. 7-8, pp. 327-338, Beograd, Srbija.

19. Stojanović, B., Radivojević, V. (2011): Economic glance at antitrust legislation in Serbia and others Western Balkan countries: Case study - dairy products market. Journal for Business and Economics, Academic Star Publishing Company, Vol. 2, No. 6, pp. 472487, New York.

20. U.S. Department of Justice, Federal Trade Commission (2010): Horizontal merger guidelines. Washington, U.S.A. (Retrieved from https:/www.ftc.gov/sites/default/files/ attachments/merger-review/100819hmg.pdf 2016 Jan 17).

\title{
MERENJE I ANALIZA INTENZITETA KONKURENCIJE NA TRŽIŠTU ŠEĆERA U SRBIJI
}

\author{
Bojan Krstić ${ }^{8}$, Vladimir Radivojević 9 , Tanja Stanišićc ${ }^{10}$
}

\begin{abstract}
Rezime
Intenzitet konkurencije je važan faktor društvenog blagostanja u svim tržišnim privredama. Svrha ovog rada jeste utvrđivanje metodološkog okvira za merenje $i$ analiziranje intenziteta konkurencije na tržištu šećera u Srbiji. Postoji više indikatora intenziteta konkurencije koji se koriste $u$ analizi tržišta. Rezultati dobijeni primenom ovih indikatora pružaju dobru osnovu za objektivno, nepristrasno i u određenoj meri standardizovano rasuđivanje i identifikaciju nekonkurentnog ponašanja. Istraživanje je realizovano primenom deskriptivne statistike, komparativne i korelacione analize. Rezultati dobijeni merenjem intenziteta konkurencije na tržištu šećera u Srbiji ukazuju na značajne probleme u procesu izgradnje efikasne tržišne privrede u Republici Srbiji. Rad je koristan organu za zaštitu konkurencije, jer pruža značajne rezultate konkurentskih uslova na tržištu šećera u Srbiji, ali i istraživačima u oblasti analize tržišta, jer im pruža primenljivi metodološki okvir za merenje i analiziranje intenziteta konkurencije na tržištima drugih proizvoda u okviru kompleksnih procesnih industrija.
\end{abstract}

Ključne reči: konkurencija, tržišna koncentracija, tržišna moć, tržište šećera, Srbija

8 Vanredni profesor, dr Bojan Krstić, Univerzitet u Nišu, Ekonomski fakultet, Trg Kralja Aleksandra Ujedinitelja br. 11, 18000 Niš, Srbija, Telefon: +381 18528 685, E-mail: bojan. krstic@eknfak.ni.ac.rs

9 Dr Vladimir Radivojević, Načelnik finansijske službe, Ministarstvo odbrane Republike Srbije, Vojska Srbije, Čegarska ulica, 18000 Niš, Srbija, Telefon: +381 18456 1926, E-mail: vladimir.radivojevic@ymail.com

10 Docent, dr Tanja Stanišić, Univerzitet u Kragujevcu, Fakultet za hotelijerstvo i turizam u Vrnjačkoj Banji, Vojvođanska ulica, 36210 Vrnjačka Banja, Srbija, Telefon: +381 64494 15 42, E-mail: tanja.stanisic@kg.ac.rs 